Economics Series

No. 115, March 2011

Inflationary Effect of Oil-Price Shocks in an Imperfect Market: A Partial Transmission InputOutput Analysis

Libo Wu, Jing Li, and ZhongXiang Zhang

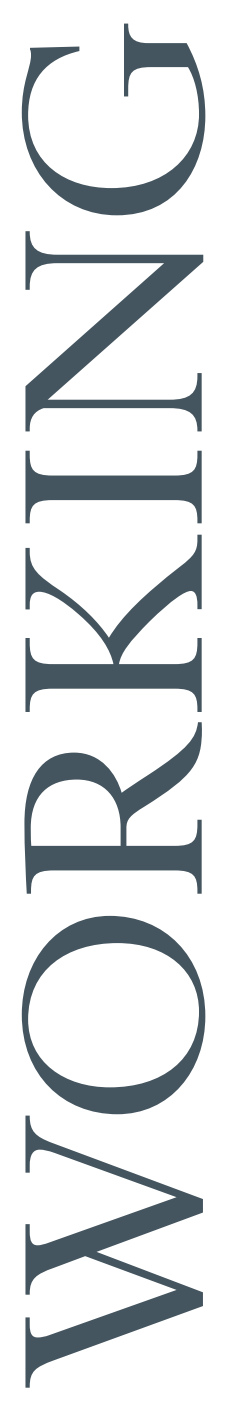

五 
The East-West Center promotes better relations and understanding among the people and nations of the United States, Asia, and the Pacific through cooperative study, research, and dialogue. Established by the U.S. Congress in 1960, the Center serves as a resource for information and analysis on critical issues of common concern, bringing people together to exchange views, build expertise, and develop policy options.

The Center's 21-acre Honolulu campus, adjacent to the University of Hawai'i at Mānoa, is located midway between Asia and the U.S. mainland and features research, residential, and international conference facilities. The Center's Washington, D.C., office focuses on preparing the United States for an era of growing Asia Pacific prominence.

The Center is an independent, public, nonprofit organization with funding from the U.S. government, and additional support provided by private agencies, individuals, foundations, corporations, and governments in the region.

East-West Center Working Papers are circulated for comment and to inform interested colleagues about work in progress at the Center.

For more information about the Center or to order publications, contact:

Publication Sales Office

East-West Center

1601 East-West Road

Honolulu, Hawai‘i 96848-1601

Telephone: 808.944 .7145

Facsimile: 808.944.7376

Email: EWCBooks@EastWestCenter.org

Website: EastWestCenter.org 
들 E A S T - W E S T CEN T E R COllaboration - ExPERTISE - LEadership

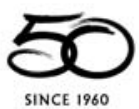

\section{Economics Series}

No. 115, March 2011

\section{Inflationary Effect of Oil-Price Shocks in an Imperfect Market: A Partial Transmission Input- Output Analysis}

Libo Wu, Jing Li, and ZhongXiang Zhang

Libo $\mathrm{Wu}$ is an associate professor from School of Economics, and Executive Director, Center for Energy Economics and Strategy Studies, Fudan University, Shanghai, China.

Jing $\mathrm{Li}$ is a graduate student from School of Economics, Fudan University, Shanghai, China.

ZhongXiang Zhang is a senior fellow at the East-West Center. Currently, he is a co-editor of both Environmental Economics and Policy Studies (the official journal of the Society of Environmental Economics and Policy Studies) and International Journal of Ecological Economics and Statistics, and serves on the editorial boards of nine leading international journals and two Chinese journals. Eleven of his publications are cited by IPCC Climate Change 2001: Mitigation and IPCC Climate Change 2007: Mitigation of Climate Change.

East-West Center Working Papers: Economics Series is an unreviewed and unedited prepublication series reporting on research in progress. The views expressed are those of the author and not necessarily those of the Center. Please direct orders and requests to the East-West Center's Publication Sales Office. The price for Working Papers is $\$ 3.00$ each plus shipping and handling. 


\title{
Inflationary effect of oil-price shocks in an imperfect market: a partial transmission input-output analysis
}

\author{
Libo $\mathrm{Wu}^{\mathrm{a}, \mathrm{d}}$, Jing $\mathrm{Li}^{\mathrm{b}}$, ZhongXiang Zhang ${ }^{\mathrm{c}^{*}}$ \\ ${ }^{a}$ Center for Energy Economics and Strategy Studies, Fudan University, No. 600 \\ Guoquan Road, Shangha, 200433, China \\ b Department of World Economy, School of Economics, Fudan University, No. \\ 600 Guoquan Road, Shanghai 200433, China \\ ${ }^{\mathrm{c}}$ Research Program, East-West Center, 1601 East-West Road, Honolulu, HI \\ 96848-1601, USA \\ d Institute of World Economy, Fudan University, No. 600 Guoquan Road, \\ Shanghai 200433, China
}

\begin{abstract}
This paper aims to examine the impacts of oil-price shocks on China's price levels. To that end, we develop a partial transmission input-output model that captures the uniqueness of the Chinese market. We hypothesize and simulate price control, market factors and technology substitution - the three main factors that restrict the functioning of a price pass-through mechanism during oil-price shocks. Using the models of both China and the U.S., we separate the impact of price control from those of other factors leading to China's price stickiness under oil-price shocks. The results show a sharp contrast between China and the U.S., with price control in China significantly preventing oil-price shocks from spreading into its domestic inflation, especially in the short term. However, in order to strengthen the economy's resilience to oil-price shocks, the paper suggests a gradual relaxing of price control in China.
\end{abstract}

JEL classification: Q43; Q41; Q48; O13; O53; P22; E31

Keywords: Oil-price shocks; Price transmission; Price control; Input-output analysis; Inflation; Industrial structure; China; the United States

Corresponding author. ZhongXiang Zhang, Senior Fellow, Research Program, East-West Center, 1601 East-West Road, Honolulu, HI 96848-1601, USA

Tel.: +1-808-944 7265; fax: +1-808-944 7298 .

E-mail address: ZhangZ@EastWestCenter.org 


\section{Introduction}

\subsection{Oil-price Shocks and China's Economic Performance}

Inflationary impacts of oil-price shocks have always concerned oil importing countries. China's dependence of oil imports has increased by more than $30 \%$ over the past decade, implying that China is becoming more sensitive or even more vulnerable to external oil price shocks. However, China's economy has managed to maintain a stunning growth for the past 10 years, despite the rapid increase of world oil prices since 2003. China's oil consumption continues to expand largely unaffected by the most oil-price shocks (see Figure 1). Most notably, China's economy maintained its growth momentum in the recent oil-price spurring period of 2007 to 2008, during which time China's consumer price index (CPI) was far less influenced than other developed nations (see Figure 2).

Like many other emerging countries, China's economic development is characterized by high energy intensity and low energy efficiency. While the oil intensity of economic output has been decreasing during past several years, it is still much higher than other developed economies in absolute terms. A relatively high oil intensity for GDP, combined with China's increasing dependence on oil imports, would make China vulnerable to international oil-price shocks. However, China's performance does not follow all these inferences and thus needs further investigation. 


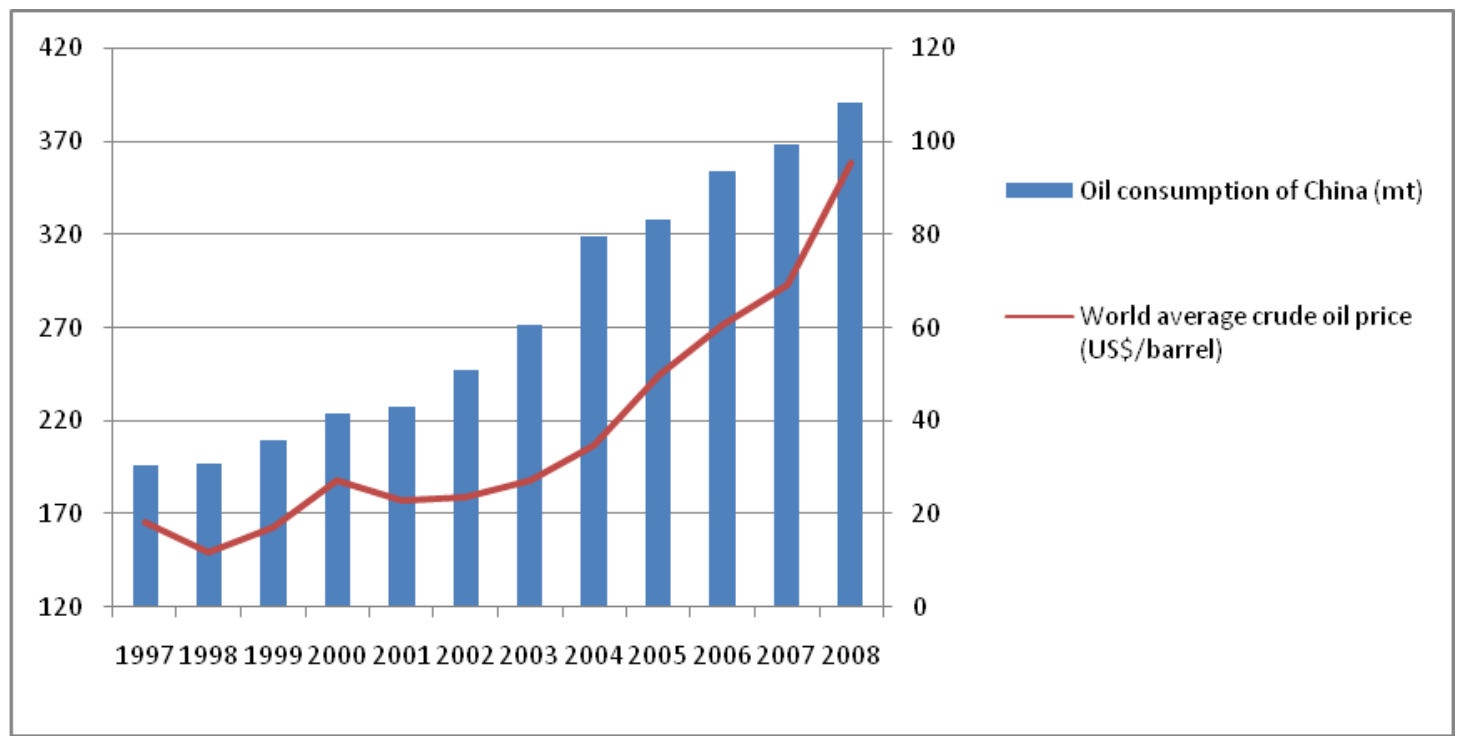

Fig.1 Oil consumption of China vs. the world's average crude oil price

Sources: Oil consumption from British Petroleum (2008); world oil prices from the U.S. Energy Information Administration (2010).

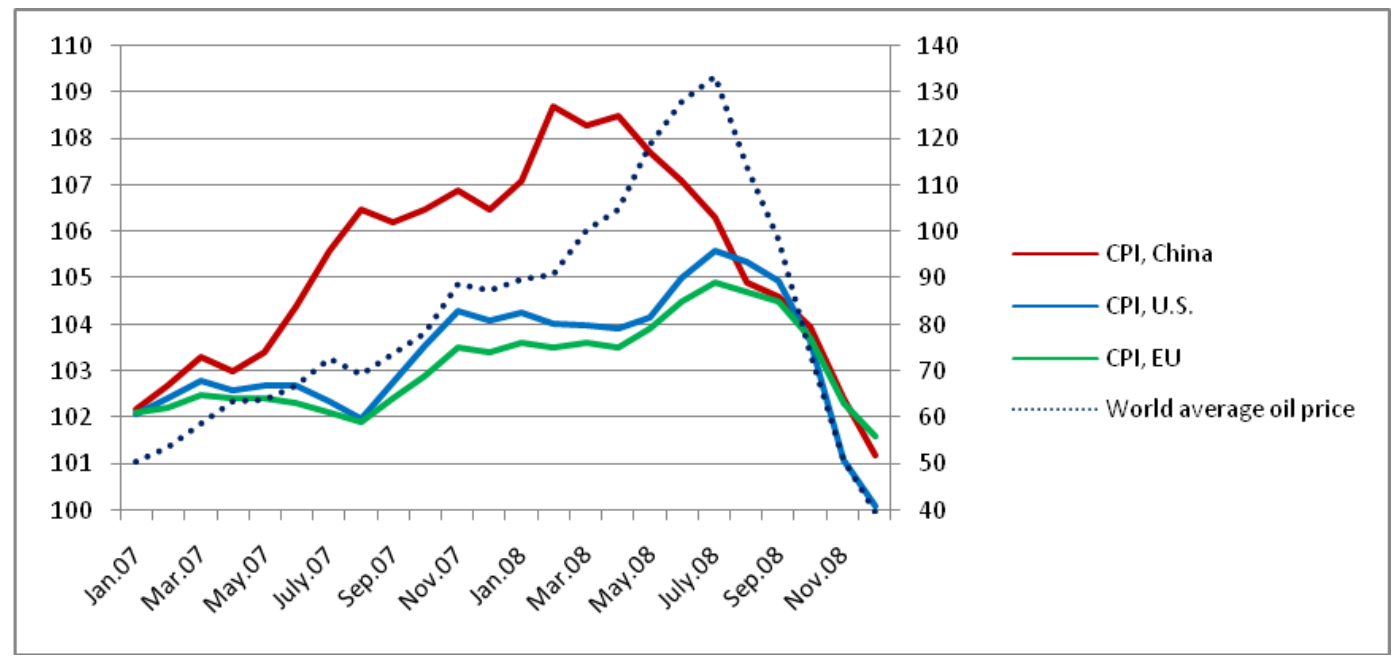

Fig.2 A comparison of CPI in China, EU, and the U.S. vs. the world's average oil price

Sources: CPI for China and the EU from National Bureau of Statistics of China 
(2010) and the OECD (2010); CPI for the U.S. calculated from the original data from Bureau of Labor Statistics of the U.S. Department of Labor (2011); world oil prices from the U.S. Energy Information Administration (2010).

\subsection{Oil-price Shocks and China's Price Control Policy}

Relying on theoretical verification and empirical observation, we would like to hypothesize that China's lessened vulnerability may be partly due to China's price control policy. Despite the continuous efforts towards price liberalization, a certain level of price control is still imposed on China's economy.

In China, price control policy targets two kinds of commodities: fundamental resources and CPI-indexed commodities. Since those industries producing the first category of commodities are prone to be monopolized, price control is implemented mainly to prevent the monopoly from encroaching on public interest. Measures taken are to keep their profit at reasonable levels. For the second category, price control is enforced to restrain inflation and to mitigate the impact of price turbulence on the general public's lives. Price control policy has acted as a useful tool in controlling inflation in China for a long period of time. However, what remains unknown is the extent of this price control, and most importantly, how this extent of price control has influenced China's responses to an oil-price shock. 


\subsection{Recent Studies}

Over the past decade, there has been a growing body of literature that has examined China's economic development under international oil-price shocks. Adopting a VAR model, Du et al. (2010) find that while China's GDP growth is positively correlated with the world oil price, oil-price shocks can have a significant impact on domestic inflation. Faria et al. (2009) examine the reasons behind the rapid expansion of the Chinese exports under oil-price shocks. Huang and Guo (2007) investigate the impact of oil-price shocks on China's real exchange rate.

However, not until recently have researchers brought the issue of China's sticky oil price pass-through into their research framework. Tang et al. (2010) observe China's price stickiness in the oil price pass-through, and using a SVAR model they show that price stickiness and rigidity of investment in a short period make the impact of oil-price shocks on China's economy gradual but permanent. Using an input-output model, Ren et al. (2007) measure the impact of oil price on China's price index and attribute the stickiness of China's oil price pass-through to such factors as market competition, price control and energy substitution.

Despite the number of studies focused on China's partial oil-price transmission mechanism, it is still unclear how different factors have contributed to the stickiness of China's oil price pass-through. In particular, how and to what extent does China's price control policy affect its price index and economic 
development under recurring international oil-price shocks? To address these questions, we will develop a unique China model in the remaining part of this paper. Section 2 introduces the modeling framework of our analysis. We tailor the traditional input-output method to better reflect the uniqueness of China's reality. In Section 3, we manage to separate the effect of price control from that of other factors leading to China's price stickiness under oil-price shocks, using the partial transmission input-output models of both China and the U.S.. Section 4 discusses some policy implications. The conclusions are drawn in Section 5.

\section{The Model}

The input-output (IO) analysis is a powerful tool in determining the gradual inflationary effect of oil-price shocks. Therefore, we have adopted an IO framework for our study. However, given the built shortcomings in the traditional IO model, we have developed a partial transition IO model to better reflect the imperfect market conditions in China.

\subsection{Why Input-output Analysis?}

The advantage of an IO analysis can be observed at least from the following three perspectives: 
First, IO modeling is specialized in analyzing the "cost-driven inflation", while China's inflation observed during the last oil-price shock is just characterized as "cost-driven", during which time international market had seen steep rise in metal, energy and grain prices - which largely led to China's high inflation rate during the period. Secondly, an oil-price shock is gradually realized through the inter-connection between industries. Meanwhile, the IO table gives a comprehensive structural description of the entire economy in a particular year (Carter, 1974; Leontief, 1986). Therefore by using the information provided by an IO table, an IO model enables us to dissect the complex interdependencies of industries within an economy, and measure the complete inflationary effect of oil-price shocks. Thirdly, while other empirical methods ignore the indirect or ripple effects, an IO analysis allows to capture inter-industry linkages and measures both the direct and indirect effects of oil-price shocks (Christian and Klaus, 2009, Liu and Ren, 2006).

\subsection{Traditional Input-output Analysis}

\section{Major Consumptions}

Three main consumptions are built in an IO analysis:

First, the demand-driven nature. All input requirements for the production of some exogenously given demand will be automatically and instantaneously met. Secondly, instant transmission. The price turbulence in upstream industries can be 
completely and instantaneously transmitted to downstream industries. Thirdly, fixed technical coefficients. The cost reduction efforts made by manufacturers through technology innovation are not considered.

The demand-driven nature of an IO model may not be justifiable for a Western economy (Giarrantani, 1976); however, given the abundant unused capacity of China, this assumption may work for our analysis. The "instant transmission" assumption of an IO model ignores any possible impediment in the transmission of oil-price shocks; and thus exaggerates the effect of oil-price shocks. Since this is usually not the case in reality, we will ease this assumption in Section 2.3. The ignorance of technical innovations in an IO model may not be justifiable in the long term; however, this may reflect the short-term reality in China. As we will further discuss in Section 4, the price control in China actually discourages manufacturers from applying energy-saving technologies to reduce their costs when oil price rises.

\section{Traditional Input-output Methodology}

Under the assumptions discussed above, a price increase in industry $i$ of $\Delta p_{i}$ will lead to a cost rise in industry $j$, which uses products from industry $i$ by $\Delta p_{i} a_{i j}$, where $a_{i j}$ is the corresponding direct requirement coefficient. Likewise, to keep profit steady, industries other than industry $i$ will have to increase their prices by 


$$
\Delta p_{i}\left[\begin{array}{lllllll}
a_{i 1} & a_{i 2} & \ldots & a_{i, i-1} & a_{i, i+1} & \ldots & a_{i n}
\end{array}\right]^{T},
$$

with the matrix form of $\Delta p_{i} a_{i}^{T}$, where $a_{i}$ represents the vectors in row $i$ excluding $a_{i i}$. This reflects the first-round effect of a price shock in the upstream industry.

The price rise of other products incurred by the initial price surge in industry $i$ will gradually lead to the ripple effects on other industries. The second round of a price shock can be shown by

$$
\left(\Delta p_{i} a_{i} A\right)^{T} \text {, or } \Delta p_{i} A^{T} a_{i}^{T}
$$

and

$$
\left(\Delta p_{i} a_{i} A \cdot A\right)^{T}, \text { or } \Delta p_{i}\left(A^{2}\right)^{T} a_{i}^{T}
$$

for the third round...The total inflationary effects of the initial price shock can be summarized into

$$
\Delta p_{i}\left[a_{i}^{T}+A a_{i}^{T}+\left(A^{2}\right)^{T} a_{i}^{T}+\left(A^{3}\right)^{T} a_{i}^{T} \ldots\right]=\Delta p_{i}\left(1-A^{T}\right)^{-1} a_{i}^{T} .
$$

This is the famous Leontief's inversion method (Leontief, 1986). It represents both the direct and indirect impacts of a price shock, initiated from industry $i$ on other industries. The Leontief's inversion method enables us to calculate the total effect of a price shock. In order to further analyze the marginal changes in price level under oil-price shocks, we will adopt the iteration method to simulate the gradual price change during an oil-price shock. 


\subsection{Partial Transmission Input-output Model}

As the traditional IO model reflects the inflationary effect of a price shock in an ideal world, the ultimate impact of the initial price surge is certainly not as significant and swift as the model indicates, due to a number of factors, such as market competition pressure, technology innovation, energy substitution, etc. Most notably, price control policies on certain commodities are still implemented in China today, suggesting the need to modify the traditional IO model to better reflect the real economy and derive the realistic results. In this section, we will introduce some new concepts into the traditional IO model. Specifically, we will incorporate the "frictions" in China's price transmission mechanism into the traditional IO model, quantify the impacts of such frictions and thus better simulate the price pass-through during an oil-price shock.

\section{Capability of Transmitting Cost}

Since the real price adjustment scale may not be as great as the cost increase level, we use the ratio of "real price increase" to "ideal price increase" to reflect the capability of an industry in transmitting its cost pressure to downstream industries. Here the "ideal price increase" equals the weighted average cost increase, assuming that an upstream manufacturer can fully transmit its cost increase to downstream manufacturers. The cost increase for each input is derived from CPI indices, while the cost weights for each industry are obtained from the 
corresponding columns in the IO direct requirement tables. We term this ratio as “capability of transmitting cost (CTC)". 2

We denote $\Delta r p_{j}$ as the real price increase, and $\sum_{i=1}^{n} p_{i} a_{i j}$ as the weighted cost increase or "ideal price increase". Therefore, the "capability of transmitting cost (CTC)" can be written as

$$
\mathrm{CTC}_{j}=\frac{\Delta r p_{i}}{\sum_{i=1}^{n} \Delta p_{i} a_{i j}}
$$

CTC is a row vector. Intuitively, the greater the capability of transmitting cost, the greater the ability of industry to pass cost pressures to other industries by raising its price. The empirical results of CTC are shown in Section 3. Given the values of CTC, we can understand how under a certain level of cost increase, producers are capable of transmitting their cost pressures or to what level they can raise their prices.

\section{Partial Transmission IO Model}

Arguably, CTC contains valuable information regarding frictions in price transmission mechanism. In light of this, our next step is to modify the "direct

${ }^{2}$ Ren et al. (2008) introduce the concept of "capability of transmitting cost" in order to illustrate the capability of different industries in transmitting cost pressure during inflation. Here we broaden the scope of its application by incorporating CTC into the traditional IO model to create the "partial transmission IO model". 
requirement table" by using the CTC matrix. By using the modified direct requirement table, our aim is to create a "partial transmission IO model", which considers price transmission frictions on top of IO relations between industries.

The modified direct requirement table is denoted as $A^{\prime}$

$$
A_{i j}{ }^{\prime}=C T \mathrm{C}_{j}{ }^{\mathrm{T}} \cdot A_{i j}
$$

and

$$
\mathrm{a}_{i j}{ }^{\prime}=C T C_{j} \cdot a_{i j}
$$

$A^{\prime}$ is obtained by multiplying every coefficient in the original direct requirement table by the corresponding "capability of transmitting cost" of the output industry. Using the modified direct requirement table $A^{\prime}$, the total impact of an oil-price shock on inflation can be obtained by summarizing all rounds of price shocks, calculated by means of

$$
\Delta p_{i}\left[\left(a_{i}\right)^{T}+A^{\prime T}\left(a_{i}^{\prime}\right)^{T}+\left(A^{\prime 2}\right)^{T}\left(a_{i}\right)^{T}+\left(A^{\prime 3}\right)^{T}\left(a_{i}{ }^{\prime}\right)^{T} \ldots\right] .
$$

Here,

$$
\mathrm{a}_{i j}{ }^{\prime}=C T C_{j} \cdot a_{i j}
$$

$\mathrm{a}_{i j}$ ' contains information from both sides: the cost composition (from the original direct requirement coefficient) and the capability of transmitting cost for each industry. For example, when cost of the $i_{t h}$ input of the $j_{t h}$ industry increases by $\mathrm{x} \%$, with all other costs remaining unchanged, it will increase the cost of the $j_{t h}$ industry by $\left(\mathrm{x}^{*} \mathrm{a}_{\mathrm{ij}}\right)$ percent; since the $j_{\text {th }}$ industry is only capable of transmitting 
$\mathrm{CTC}_{\mathrm{j}}$ (in percentages) of its cost rise, the initial price increase should be $\left(x^{*} a_{i j} * C T C\right.$, i.e. $\left(x^{*} a_{i j}{ }^{\prime}\right)$. This initial price increase will then spread into other industries, thus resulting in a cost-driven inflation. Because this new IO model reflects baffled price transmission mechanism in reality, we call it the "partial transmission input-output model".

\subsection{Multi Scenario Analysis}

With the partial transmission IO model introduced above, we will now develpe two scenarios, using data from both China and the U.S., in an effort to identify factors in blocking price pass-through during oil-price shocks. We take the U.S. as a reference because it is considered as the freest market in the world, with little intervention from the government. Most of the frictions in price transmission in the U.S. result from the market itself, rather than price control policies of the government. On the contrary, the baffled price transmission mechanism in China is a result of both government intervention and market factors. Therefore, a comparison between China and the U.S. scenarios can give us valuable information regarding the relative impact of different transmission frictions in price pass-through mechanisms.

\section{Scenario I: Complete Transmission}


Under this scenario, we ignore the factors that baffle a price pass-through during an oil-price shock, and use the traditional IO method to determine the maximum impact of an oil-price shock on general price level. Simulation results of a hypothetical $100 \%$ oil-price increase under this scenario are derived using data from both China and the U.S. (see Section 3).

\section{Scenario II: Partial Transmission}

Under the assumption that price adjustment is baffled by distorted price mechanism, we use the "partial transmission IO model" to simulate the inflation level during a hypothetical oil-price shock. Arguably, simulation results in both countries under this scenario should be smaller and more plausible compared with that under Scenario I.

\section{Data, Empirical Results and Discussion}

\subsection{Data}

In the calculation of CTC, recall

$$
\mathrm{CTC}_{j}=\frac{\Delta r p_{i}}{\sum_{i=1}^{n} \Delta p_{i} a_{i j}}
$$


$a_{i j}$ comes from direct IO tables. Here we use the 2007 China IO table (National Bureau of Statistics of China, 2009) and the 2002 U.S. benchmark IO table (Bureau of Economic Analysis of the U.S. Department of Commerce, 2008), both of which are the latest available IO tables.

For $\Delta r p_{i}$, we use relevant monthly CPI and PPI (producer price index) indices between July 2007 and July 2008 to calculate "real price increase" from July 2007 to July 2008. Similarly, we use the corresponding CPI and PPI indices during the same period to represent cost increase $\left(\Delta p_{i}\right)$ of different inputs for different industries.

The reason why we use price variance data from July 2007 to July 2008 is because, to calculate CTC, we need to choose a period during which many industries face cost surges so that we can observe whether producers are sufficiently able to increase their prices. Meanwhile, the world has experienced unprecedented oil-price shocks over the same period, during which the world's average crude oil price rose from 73 to 134 US\$/barrel. As a result, both China and the U.S. have seen sharp increases in the inflation rates (see Figure 2). This enables us to observe producers' responses to wide-spread cost surges and quantify their capability of transmitting costs.

\subsection{Capability of Transmitting Cost}

As would be expected, the CTC coefficients vary from one industry to another, 
with patterns widely differentiated between China and the U.S..

Table 1

Ten Chinese industries with the highest CTCs and ten with the lowest CTCs

\begin{tabular}{|l|l|l|l|}
\hline $\begin{array}{l}\text { Industries with the highest } \\
\text { CTCs }\end{array}$ & CTC & $\begin{array}{l}\text { Industries with the lowest } \\
\text { CTCs }\end{array}$ & CTC \\
\hline Financial services & 13.18 & $\begin{array}{l}\text { Information, computer services } \\
\text { and software }\end{array}$ & -1.03 \\
\hline Oil and gas extraction & 8.37 & $\begin{array}{l}\text { Communications equipment, } \\
\text { computer and other electronic } \\
\text { instrument manufacturing }\end{array}$ & -0.96 \\
\hline Waste products and materials & 5.75 & $\begin{array}{l}\text { Culture, sports and } \\
\text { entertainment }\end{array}$ & -0.29 \\
\hline $\begin{array}{l}\text { Agriculture, forestry, fishing and } \\
\text { herding }\end{array}$ & 4.46 & Post services & 0.00 \\
\hline Coal mining & 4.01 & $\begin{array}{l}\text { Electric power, heat generation, } \\
\text { transmission and distribution }\end{array}$ & 0.15 \\
\hline Metal ores mining & 3.55 & $\begin{array}{l}\text { Transportation equipment } \\
\text { manufacturing }\end{array}$ & 0.16 \\
\hline $\begin{array}{l}\text { Nonmetallic mineral mining and } \\
\text { quarrying }\end{array}$ & 2.39 & $\begin{array}{l}\text { Device, office equipment } \\
\text { manufacturing }\end{array}$ & 0.16 \\
\hline Real estate & 2.06 & Chemistry & 0.27 \\
\hline $\begin{array}{l}\text { Health, Social security and social } \\
\text { benefit }\end{array}$ & 1.53 & $\begin{array}{l}\text { Electronic equipment } \\
\text { manufacturing }\end{array}$ \\
\hline distribution & 0.24 \\
\hline
\end{tabular}

Table 2

Ten U.S. industries with the highest CTCs and ten with the lowest CTCs 


\begin{tabular}{|c|c|c|c|}
\hline $\begin{array}{l}\text { Industries with the highest } \\
\text { CTCs }\end{array}$ & CTC & $\begin{array}{l}\text { Industries with the lowest } \\
\text { CTCs }\end{array}$ & CTC \\
\hline $\begin{array}{l}\text { Securities, commodity contracts, } \\
\text { investments, and related activities }\end{array}$ & 31.18 & $\begin{array}{l}\text { Computer and peripheral } \\
\text { equipment manufacturing }\end{array}$ & -262.50 \\
\hline Oil and gas extraction & 24.60 & $\begin{array}{l}\text { Funds, trusts, and other } \\
\text { financial vehicles }\end{array}$ & -3.95 \\
\hline $\begin{array}{l}\text { Monetary authorities, credit } \\
\text { intermediation and related } \\
\text { activities }\end{array}$ & 13.88 & Owner-occupied dwellings & -2.89 \\
\hline Legal services & 10.87 & $\begin{array}{l}\text { Travel arrangement and } \\
\text { reservation services }\end{array}$ & -2.43 \\
\hline Water, sewage and other systems & 10.59 & $\begin{array}{l}\text { Lessors of nonfinancial } \\
\text { intangible assets }\end{array}$ & -2.13 \\
\hline $\begin{array}{l}\text { Automotive equipment rental and } \\
\text { leasing }\end{array}$ & 10.55 & Telecommunications & -2.04 \\
\hline Real estate & 8.72 & $\begin{array}{l}\text { Semiconductor and other } \\
\text { electronic component } \\
\text { manufacturing }\end{array}$ & -1.74 \\
\hline Rail transportation & 7.71 & $\begin{array}{l}\text { Audio, video, and } \\
\text { communications equipment } \\
\text { manufacturing }\end{array}$ & -1.37 \\
\hline Wholesale trade & 7.39 & $\begin{array}{l}\text { Radio and television } \\
\text { broadcasting }\end{array}$ & -0.96 \\
\hline $\begin{array}{l}\text { Management, scientific, and } \\
\text { technical consulting services }\end{array}$ & 7.17 & $\begin{array}{l}\text { Computer systems design and } \\
\text { related services }\end{array}$ & -0.43 \\
\hline
\end{tabular}

The industries "oil and gas extraction" of both countries are among the top-10 CTC list, indicating that oil and gas prices are more driven by demand factors rather than cost turbulence. However, China has more mining industries on the top-10 CTC list (coal mining, metal ores mining, etc), implying better bargaining power of upstream energy producers in China. Financial services and 
the real estate industry have similar high levels of CTCs in both China and the U.S., consistent with the common sense that these industries set prices according to the benchmark price level (often set by influential manufacturers in the industry), rather than their costs. As for industries with the lowest CTCs, China and the U.S. follow more or less the same pattern: information-related industries occupy most of the list; their negative CTCs imply that prices in these industries are mostly irrelevant to their manufacturing costs, revealing their vulnerability under a general price surge.

While some industries have CTCs well above 1 (notice those industries with the highest CTCs), other industries have very low CTCs (far less than 1), indicating little discretion in price adjustment under oil-price shocks. The reason behind manufacturers raising prices beyond cost hikes is indeed very complex. While the cost of production is among the most important factors in pricing, other factors cannot be neglected. For example, price turbulence in global market, demand surge in local market, perceived reliability of supply and supply disruption as a result of natural disasters and other unexpected events, either individually or in combination, would lead to dramatic price hikes where the cost of production has not markedly increased. Moreover, it is likely that industries having CTC larger than 1 would have taken advantage of cost hikes (e.g. oil-price shocks) by excessively adjusting their price (compared with their cost rise levels).

The phenomenon of "over-shooting" under oil-price shocks is intriguing in 
itself; but it goes beyond the scope of this paper. As mentioned above, we intend to focus on industries where price transmission has been baffled, given that IO types of models implicitly exclude the possibility of demand-driven inflation. Consequently, we will only pay attention to industries with CTC less than 1, leaving those "over-shooting" industries for future studies. Accordingly, for industries with CTC coefficients larger than 1, we adjust them to 1 , implying that manufacturers will adjust their price no greater than the level of their cost surge.

As for most industries with CTCs less than 1, it is clear that many manufacturers are not capable of fully transmitting cost to their customers. The reason behind a partial transmission in China during oil-price shocks can be attributed to such factors as price control, market factors and technology substitution, each briefly explained below.

\section{Price control}

Price control policy in China targets two kinds of commodities: fundamental resources and CPI-indexed commodities. This policy is enforced in efforts to control inflation and prevent monopoly from encroaching on the public interest. While price control policy is implemented out of goodwill and is arguably helpful in mitigating the impact of price shocks, it has made price extremely rigid and has kept industries from quickly reacting to cost shocks (see Appendix for further discussion). 


\section{Market factors}

Even in a market free of price controls (like the U.S.), producers still cannot fully transmit cost increases to their customers. This can result from several factors, market competition pressure being among one of them. For example, producers may want to keep their price level unchanged or even lower (as is the case in information industries), which have negative CTCs for both China and the U.S. ${ }^{3}$, in order to remain competitive in the market, even if their costs have been increased. There are also possibilities that demand elasticity is extremely high. Therefore a slight rise in price will cause huge decrease in demand, which deters producers from lifting their prices. In other cases, prices may be set beforehand in annual contracts; therefore producers are prohibited from raising prices, even when their costs have been markedly increased.

\section{Technology substitution}

In an economy that is frequently and severely attacked by oil-price shocks, producers will gradually find ways to adapt and counteract the negative influence of oil-price shocks by improving their manufacturing technologies. For example,

3 This implies that manufacturers lower their prices when costs rise. This may result from the highly competitive nature of information industry. Prices of new products tend to drop after hitting the market. 
they can use renewable energies instead of oil, or adopt technologies with higher energy efficiency. The technology substitution efforts made by producers will help cut costs and therefore curb inflation during oil-price shocks. However, this effect cannot be realized in the short term, especially when we consider the slow pace of technology advancement in China today.

\subsection{Oil-price Shocks and General Price Levels}

\section{General Price Level}

Applying both complete and partial transmission IO model to China and the U.S. would enable us to simulate price changes in different industries under two scenarios when crude oil price doubles, namely, increases by $100 \%$.

The IO table provides us with the composition of the final residential consumption. By using this data as the weighting number, we can have the weighted average "general price level" changes under hypothetical oil-price shocks. However, it should be pointed out that, although this number offers meaningful information regarding how consumers are affected during oil-price shocks, the so-called "general price level" is still not equal to the CPI due to different statistical approach.

\section{Simulation Results}


In an ideal world, China will experience a $4.91 \%$ increase in general consumer price level under a doubling of oil price after ten iterations (China, Scenario I). However, after the pass-through friction is taken into consideration, the general price level surge will be significantly mitigated to be only $1.39 \%$ (China, Scenario II). Also, if the price transmission is complete, the U.S. will see a $1.80 \%$ rise in its general consumer price level (U.S., Scenario I), while the price level will slightly decrease to $1.30 \%$ in a partial transmission IO model (U.S., Scenario II).

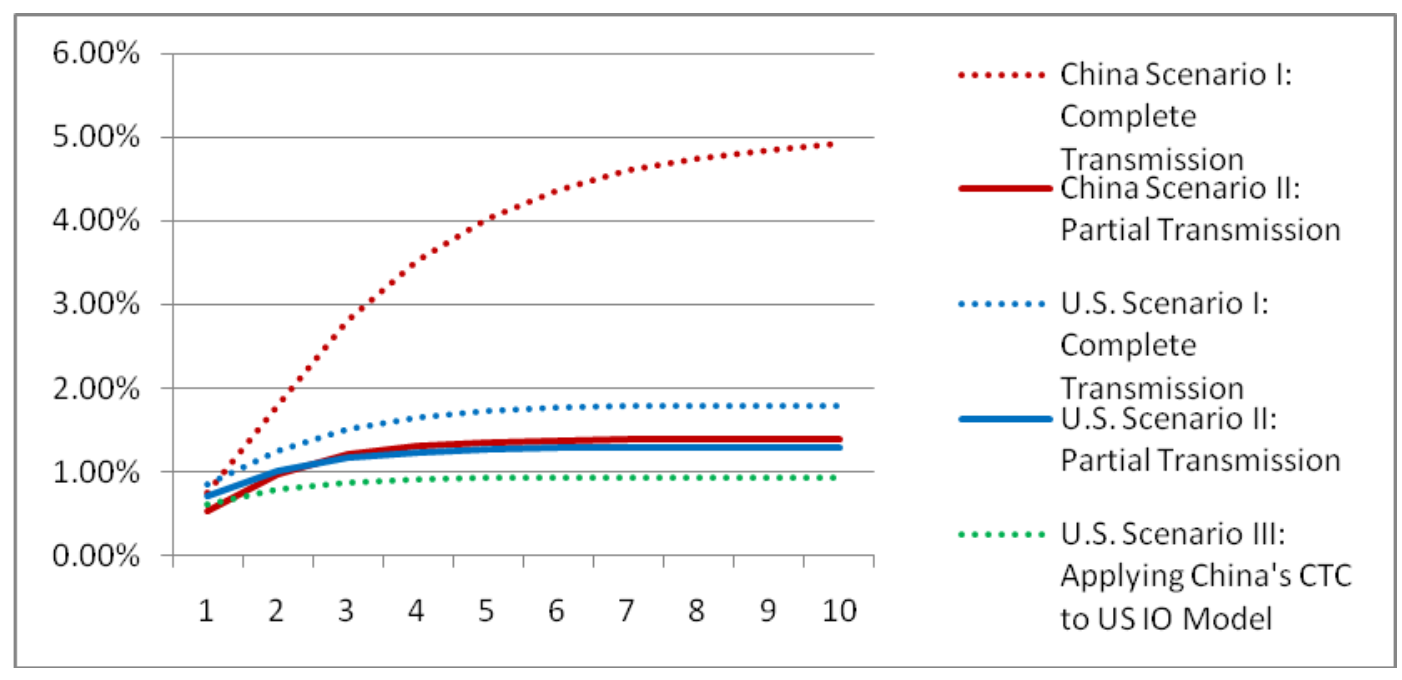

Fig.3 Simulation results of an input-output analysis for China and the U.S.

\subsection{Discussion}

Generally speaking, the impact of oil-price shocks on price levels depends on five major factors: industrial structure, oil intensity, market factors, price control, and technology substitution. Intuitively, an economy relying more heavily on the 
manufacturing industry than the service industry will be more prone to oil-price shocks. Likewise, an economy with higher oil intensity is more vulnerable to oil-price shocks than those with less oil dependence. In a market with less favorable market conditions where competition is more intense, manufacturers may feel reluctant to raise prices in order to pass through the impact of oil-price shocks. However, the price control policy distorts pricing mechanisms and mitigates the short-term impact of oil-price shocks on price levels. Moreover, the quick adaption to oil-price shocks by technology substitution can help businesses overcome oil-price shocks without raising prices.

In order to understand the impact of the aforementioned factors, we categorize the above five factors into two groups: group A (industrial structure and energy intensity) and group B (market factors, price control, and technology substitution). While the information for factors in group A can be found in the IO table, the information contained in group B are embodied in our CTC coefficients (See Table 3).

Table 3

Simulation results and the five major factors in determining the impact of oil-price shocks

\begin{tabular}{|l|l|l|l|l|l|l|}
\hline \multirow{2}{*}{} & \multirow{2}{*}{$\begin{array}{l}\text { Simulation } \\
\text { results }\end{array}$} & \multicolumn{4}{|l|}{ Major factors in determining the impact of oil-price shocks } \\
\cline { 3 - 7 } & Industrial & Oil & Market & Price & Technology \\
structure & intensity & factors & control & substitution \\
$\left(\mathrm{B}_{1}\right)$ & $\left(\mathrm{B}_{2}\right)$ & $\left(\mathrm{B}_{3}\right)$ \\
\hline
\end{tabular}




\begin{tabular}{|l|l|l|l|l|l|l|}
\hline $\begin{array}{l}\text { China } \\
\text { Scenario I }\end{array}$ & $4.91 \%$ & $\mathrm{~A}_{1}^{c}$ & $\mathrm{~A}_{2}^{c}$ & & \\
\hline $\begin{array}{l}\text { China } \\
\text { Scenario II }\end{array}$ & $1.39 \%$ & $\mathrm{~A}_{1}^{c}$ & $\mathrm{~A}_{2}^{c}$ & $\mathrm{~B}_{1}^{c}$ & $\mathrm{~B}_{2}^{c}$ & $\mathrm{~B}_{3}^{c}$ \\
\hline $\begin{array}{l}\text { The U.S. } \\
\text { Scenario I }\end{array}$ & $1.80 \%$ & $\mathrm{~A}_{1}^{u}$ & $\mathrm{~A}_{2}^{\mathrm{u}}$ & & & \\
\hline $\begin{array}{l}\text { The U.S. } \\
\text { Scenario II }\end{array}$ & $1.30 \%$ & $\mathrm{~A}_{1}^{\mathrm{u}}$ & $\mathrm{A}_{2}^{\mathrm{u}}$ & $\mathrm{B}_{1}^{\mathrm{u}}$ & $\mathrm{B}_{2}^{u}$ & $\mathrm{~B}_{3}^{u}$ \\
\hline
\end{tabular}

Note: Superscript "u" and "c" represent the U.S. and China, representatively.

With simulation results in the above two scenarios for China and the U.S., we now arrange these two groups of factors into the following numerical relationships:

$A_{1}^{c} \cdot A_{2}^{c}=4.91 \%$

$A_{1}^{c} \cdot A_{2}^{c} \cdot B_{1}^{c} \cdot B_{2}^{c} \cdot B_{3}^{c}=1.39 \%$

$A_{1}^{u} \cdot A_{2}^{u}=1.80 \%$

$A_{1}^{\mathrm{u}} \cdot A_{2}^{u} \cdot B_{1}^{u} \cdot B_{2}^{u} \cdot B_{3}^{u}=1.30 \%$

Combining equations (1) and (2), as well as equations (3) and (4), we have

$$
B_{1}^{c} \cdot B_{2}^{c} \cdot B_{3}^{c}=28.31 \%, B_{1}^{u} \cdot B_{2}^{u} \cdot B_{3}^{u}=72.22 \%
$$

Here the residual value of $\left(1-B_{1} \cdot B_{2} \cdot B_{3}\right)$ show us the level of inflation that will be mitigated by taking factors in group B (market factors, price control, and technology substitution) into consideration. Based on our calculations, the 
combination of market factors, price control and technology substitution will push the inflation rate in China down by $71.69 \%\left(1-B_{1}^{c} \cdot B_{2}^{c} \cdot B_{3}^{c}\right)$, while these three factors will mitigate the inflation rate in the U.S. only by $21.78 \%\left(1-B_{1}^{u} \cdot B_{2}^{u} \cdot B_{3}^{u}\right)$. Also, the difference between $A_{1}^{c} \cdot A_{2}^{c}(4.91 \%)$ and $A_{1}^{u} \cdot A_{2}^{u}(1.80 \%)$ shows that the less industry-oriented economic structure and lower oil intensity in the U.S. help mitigate inflation by $3.11 \%$ in absolute terms or $63.34 \%$ in relative terms.

To further separate the impact of price control from other influences, we need to examine these factors more closely. To that end, we need to make the necessary assumptions.

\section{Technology substitution}

Ideally, in the face of an oil shock, some manufacturers may counteract the negative impact through technical innovation, by adopting less oil-intensive technology and/or substituting oil with other type of energy. Substituting a technology to mitigate the impact of oil-price shocks is based on two prerequisites: adequate technology competency and quick technology transformation pace. Although the reoccurring oil-price shocks have prodded industries to find alternative energies or develop more oil-efficient technologies, it will usually take quite some time before the technologies come to commercialization. Therefore, the effect of technology substitution may not be reflected during the current round of an oil-price shock, but will help counteract the risks of oil-price shocks in the 
future. In light of this, we assume that the factor of "technology substitution" can be neglected in the near term, both in the U.S. and in China, namely, $B_{3}^{u}=B_{3}^{c}=100 \%$.

\section{Market factors}

Market factors, such as willingness to remain competitive, high price elasticity and fixed contracts, are the major causes behind partial price pass-through, especially for a free markets like the U.S.. The significance of market factors in determining oil price pass-through is dependent very much on the bargaining power of different industries. In a market where competition is very intensive or where products have very high price elasticity, suppliers are expected to have lower bargaining power and are more likely to bear the cost during oil-price shocks, or sign fixed contracts which expose themselves to future cost shocks.

The terms of trade index compares export price change with import price change. A rise in the index means that relative export price increase exceeds relative import price increase; in other words, the trade condition is in favor of the exporting country with a rise in the bargaining power in international trade. Enlightened by this, we employ the terms of trade index published by UNCTAD (2010) to quantify the relative bargaining power of the overall economy for China and the U.S..

As shown in Figure 4, the terms of trade index of the U.S. is $24 \%$ higher 
than that of China in 2008, implying that industries in the U.S. have greater bargaining power than those in China. In other words, it is more difficult for industries in China to pass through the cost pressure.

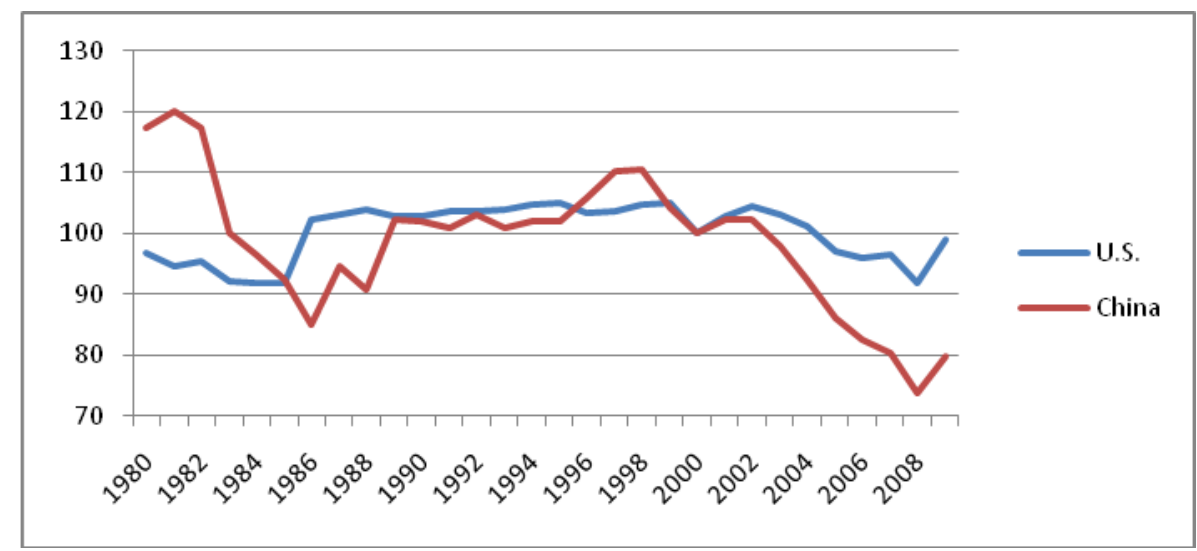

Fig. 4 Terms of trade indices for China and the U.S., 1980-2009

Source: UNCTAD (2010).

With this in mind, we assume that the retardant effect of market factors in China is $24 \%$ greater than that of the U.S., assigning $B_{1}^{u}=(1+24 \%) \cdot B_{1}^{c}$. Meanwhile, the technology substitution factor can be neglected in the short term, and no price control policy is enforced in the U.S., i.e.

$$
B_{2}^{u}=100 \%, B_{3}^{u}=B_{3}^{c}=100 \%,
$$

We have

$$
B_{1}^{u}=72.22 \%, B_{1}^{c}=58.24 \%, \quad B_{2}^{\mathrm{c}}=48.61 \% \text {. }
$$

The results show that the market factors in the U.S. and China account for a $21.78 \%$ and $41.76 \%$ decrease in the inflation rate respectively, implying that 
China's market is more stagnated than that of the U.S. in terms of transmitting the cost pressure during oil-price shocks. Meanwhile, the price control mitigates inflation by $51.39 \%$, indicating that price control in China significantly prevents producers from passing through their costs during oil-price shocks.

\section{Policy Implications}

Our empirical results have shown that China's price control policy significantly lowers the capability of China's industries in price pass-through during oil shocks. This policy prevents oil shocks from quickly spreading into downstream industries and thus helps curb inflation in the short term. However, effective as it is, the side effects of price control are very destructive for the economy.

First of all, the policy distorts price adjustment mechanisms. When international oil price surges, domestic oil price will not rise simultaneously due to an adjustment lag caused by oil price control. With domestic oil prices remaining unchanged, manufacturers will increase their current demand for oil products, since they expect oil price to rise in the near future. Consequently, oil price control turns the price elasticity of downstream manufacturers from negative to positive; the higher the international oil prices, the higher the demand, the larger the discrepancy between demand and supply for oil products. Price control, in fact, prevents the economy from reaching market equilibrium by itself. 
Secondly, price control causes manipulation and probably amplifies the overall inflationary effect. The widening gap between oil supply and demand would prod manipulation activities, driving prices in black markets higher and higher. This, in turn, increases price expectation in the regulated market and exaggerates oil shortage crises, adding enormous pressure on policy makers. When the oil price control is eventually relaxed, the oil price is sometimes increased more than enough to cover the original international oil price surge, due to higher demand for oil products. From an economic point of view, the resulting inflation is both pushed by cost and pulled by demand. As a result, although oil price control can delay the impact of oil shocks on inflation in the short term, it is possible that the overall inflationary effect is greater than that without oil price control, especially in the long term, when the expectation of oil price rise is fully realized.

Thirdly, price control discourages technical innovation. Ideally, in a market where oil price pass-through is very difficult, manufacturers will be seriously hit by oil shocks. In order to mitigate the negative impact, they will try to find alternative technologies. On the other hand, in a market where the pricing mechanism is less stagnated and manufacturers manage to pass through the cost impact, customers will choose products using less oil since their prices are less affected by oil shock. A combination of the two factors encourages producers to adopt new technologies. By contrast, because of oil price control in China, the domestic oil price fails to respond to international oil price surge in the short term. 
Therefore, downstream manufacturers have less incentive to reduce oil intensity. As a result, as the inflationary effect of oil shocks fully comes into play, the producers will be seriously hurt in the long term, since they are not fully prepared due to rigidness in oil price pass-through.

Last but not least, price control squeezes business profits and lowers investment incentives. During an oil shock, price control on oil products will gradually erode the profits of oil producers, with an increasing discrepancy between imported and domestic oil prices. After the government adjusts the domestic oil price, however, downstream manufacturers will gradually feel the cost pressure when the price shock is gradually transmitted through the industry chain. However, for those producers of CPI-indexed commodities under price control, they are incapable of further transmitting cost increase. Consequently, investment in those industries will be largely cut back, which will in turn have a negative impact on the upstream industries. As a result, the investment incentives within the whole economy will be greatly diminished, thus leading to lower chances of survival for individual business and slower recovery for the whole economy.

All the aforementioned taken into account, although price control can offset the impact of oil-price shocks in the short term, it in fact distorts price mechanism, exaggerates long-term inflation effect, discourages technical innovation and dampens investment incentives. Thus, instead of imposing a price 
control policy on commodities, efforts towards reducing energy intensity and adjusting industrial structure can be seen as a more persistent and instructive policy tool in combating inflation during oil-price shocks (less industrial structure and lower oil intensity in the U.S. help mitigate inflation by $63.34 \%$, compared with China).

In addition, lack of bargaining power is another major reason behind China's unsuccessful oil shock pass-through (this market factor decreases the inflation rate by $41.76 \%$ for China). In light of this, industrial upgrading can be considered as another long-term solution to mitigate the impact of oil shocks on China's economy.

It should be emphasized that the consequence of relaxing price control combined with efforts in reducing energy intensity, adjusting industrial structure and industrial upgrading is not as terrible as some may expect. As shown in our study, in a free market economy like the U.S., a 100\% oil-price increase will only raise the inflation rate by $1.30 \%$, which is even lower than our simulation results of China (1.39\%) under price control.

\section{Conclusions}

China's oil imports have accounted for over half of its total oil consumption and 
the oil intensity of its economy is still very much higher than that of industrialized countries. A combination of the two factors would make China's economy vulnerable to world oil-price shocks. However, China had managed to maintain its growth momentum with its CPI less influenced during the 2007-8 oil-price shock. In this paper, we attempt to explain China's lessened vulnerability to oil-price shocks by investigating the price control policy in China. To that end, we tailor the traditional IO analysis to China's uniqueness. Taking into consideration the baffled price pass-through mechanism in reality, we incorporate the capability of transmitting cost into the direct IO table and develop a partial transmission IO model. This new approach reflects the frictions in a price transmission process and thus enables us to better simulate the cost-driven inflation during oil-price shocks.

Our simulation results show that under an ideal scenario China will experience a $4.91 \%$ increase in general price level when oil price doubles; the inflation rate will drop significantly to $1.39 \%$, after factoring in the transmission friction. By contrast, the inflation rate in the U.S. will only decrease from $1.80 \%$ under a complete transmission scenario to $1.30 \%$ under a partial transmission scenario.

To further identify the factors in determining the impact of oil-price shocks, we divide those factors into industrial structure, oil intensity, market factors, price control, and technology substitution, and incorporate the five factors into the traditional IO model. Under several reasonable assumptions, we find that the 
lower industry-oriented economic structure and lower oil intensity in the U.S. help mitigate inflation by $3.11 \%$ in absolute terms or $63.34 \%$ in relative terms. Meanwhile, the market factors (including fierce competition, high demand elasticity, fixed contract, etc.) in the U.S. and China account for a $21.78 \%$ and $41.76 \%$ decrease in the inflation rate, respectively; and the price control in China mitigates inflation by $51.39 \%$.

Based on our quantitative results, we can draw the following conclusions. First, reducing oil intensity and adjusting industrial structure can be taken as a persistent and instructive policy tool in curbing inflation during oil-price shocks. Secondly, lack of bargaining power is another major reason behind China's partial oil price pass-through. Therefore, industrial upgrading is another long-term solution to mitigate the impact of oil-price shocks on China's economy. Thirdly, although price control offsets the impact of oil-price shocks in the short term, it distorts price adjustment mechanism, exaggerates long-term inflation effect, discourages technical innovation and dampens investment incentives. Consequently, relaxing price control is a necessary step towards making price pass-through mechanism work in China. Finally, the consequences of relaxing price control as well as other recommended policies are acceptable and controllable. Our simulation results show that in a free market economy like the U.S., a doubling of oil price will only raise the inflation rate by $1.30 \%$, which is even lower than our simulation results of China under price control. 


\section{References}

Anne P. Carter, 1974. Applications of input-output analysis to energy problems, Science 184 (4134), 325-329.

Bureau of Economic Analysis of the U.S. Department of Commerce, 2008. 2002 benchmark input-output data. Available at: http://www.bea.gov/industry/io_benchmark.htm.

British Petroleum, 2008. BP Statistical Review of World Energy. London.

Bureau of Labor Statistics of the U.S. Department of Labor, 2011. Consumer price index. Washington, DC, 17 February, available at: ftp://ftp.bls.gov/pub/special.requests/cpi/cpiai.txt.

Liumin Du, Yanan He, Chu Wei, 2010. The relationship between oil price shocks and China's macro-economy: an empirical analysis. Energy Policy 38 (8), $4142-4151$

João Ricardo Faria,André Varella Mollick, Pedro H. Albuquerque, Miguel A. León-Ledesma, 2009. The effect of oil price on China's exports. China Economic Review 20 (4), 793-805.

Giarratani F., 1976. Application of an interindustry supply model to energy issues. Environment and Planning 8, 447-54.

Ying Huang, Feng Guo, 2007. The role of oil price shocks on China's real exchange rate. China Economic Review 18 (4), 403-416. 
Christian Kerschner, Klaus Hubacek, 2009. Assessing the suitability of input-output analysis for enhancing our understanding of potential economic effects of peak oil. Energy 34, 284-290.

Wassily Leontief, 1986. Input-Output Economics, Oxford University Press, Cambridge.

Qiyun Liu, Zeping Ren, 2006. Estimation and empirical study on price impact model. China Price 2006.12, 35-40.

National Bureau of Statistics of China, 2009, 2007 Input-Output Tables of China. China Statistics Press, Beijing.

National Bureau of Statistics of China, 2010. General consumer price index. China Statistics Database, Beijing, available at: http://219.235.129.58/indicatorMonthQuery.do.

Organisation for Economic Co-operation and Development (OECD), 2010. Key short-term economic indicators: consumer prices - annual inflation. OECD StatExtracts, $\quad$ Paris, available at: http://stats.oecd.org/index.aspx?queryid=21761.

Zeping Ren, Wenqing Pan, Qiyun Liu, 2007. Crude oil price effects on China's price level based on input-output price model. Statistical Research 24 (11), 22-28.

Zeping Ren, Jianlong Yang, Kangping Wu, 2008. Inflation's impact on industrial climate based on CTC model. Statistical Research 25 (10), 46-53.

State Development and Planning Commission, 2001. The pricing catalogue by the 
State Development and Planning Commission and other concerned departments under the State Council. 4 July, available at: http://www.ndrc.gov.cn/zcfb/zcfbl/zcfbl2003pro/t20050707_27540.htm.

The Price Department of the National Development and Reform Commission, 2009. Thirty years of price reform in China. Economic Daily, 5 February, available at: http://cpc.people.com.cn/GB/64093/64387/8751851.html.

United Nations Conference on Trade and Development (UNCTAD), 2010. Merchandise trade indices, annual, 1980-2009 -- terms of trade indices. UnctadStat, Geneva, http://unctadstat.unctad.org/TableViewer/tableView.aspx?ReportId=119.

U.S. Energy Information Administration (2010). World crude oil prices. Washington, $\quad$ DC, available at: http://www.eia.doe.gov/dnav/pet/pet_pri_wco_k_w.htm.

Weiqi Tang, Libo Wu, ZhongXiang Zhang, 2010. Oil price shocks and their shortand long-term effects on the Chinese economy. Energy Economics 32 (Supplement 1), S3-S14. 


\section{Appendix Price Control Policy in China}

Despite the fact that prices of most commodities and services are set in the market, prices of a few commodities are still under the government's control in China. According to the Price Law, there are two kinds of price control policies: prices guided by a government and prices set by a government. For the former one, a pricing authority will set a benchmark price and its floating range. The business entity should price the commodity or service according to this regulation. As for the latter, a pricing authority stipulates the price directly.

Two sets of pricing catalogues, both at the central government level and at the local government level, define prices that should be set or controlled by the government. The central pricing catalogue is formulated by the pricing authority under the State Council (China's cabinet), which is now the price department of the National Development and Reform Commission, while the local pricing catalogue is drafted by the pricing authority of a provincial or municipal government, which should be further approved by the State Council. The central pricing catalogue was last revised in 2001, cutting pricing categories from 121 to 13 (See Table 4).

Table 4

Central pricing catalogue (2001 version)

\begin{tabular}{lll}
\hline & Category & Content \\
\hline $\mathbf{1}$ & Important central reserve & Reserve grains, edible vegetable oil, cotton, reserve \\
\hline
\end{tabular}




\begin{tabular}{lll}
\hline & commodities & $\begin{array}{l}\text { sugar, reserve oil, reserve chemical fertilizer, reserve } \\
\text { silk, }\end{array}$ \\
\hline $\mathbf{2}$ & $\begin{array}{l}\text { Tobacco, salt and civil } \\
\text { explosion equipments }\end{array}$ & Tobacco leaf, salt, civil explosion equipments \\
\hline $\mathbf{3}$ & Chemical fertilizers & Urea, ammonium nitrate, etc. \\
\hline $\mathbf{4}$ & Important medicines & $\begin{array}{l}\text { Stupefacient, specific psychotropic drugs, } \\
\text { prophylactic, etc. }\end{array}$ \\
\hline $\mathbf{5}$ & Textbooks & $\begin{array}{l}\text { Textbooks for elementary schools, middle schools, } \\
\text { universities and colleges }\end{array}$ \\
\hline $\mathbf{6}$ & Natural gas & Onshore natural gas \\
\hline $\mathbf{7}$ & Water & $\begin{array}{l}\text { Water of hydraulic projects directly managed by } \\
\text { central government and cross-provincial hydraulic } \\
\text { projects }\end{array}$ \\
\hline $\mathbf{8}$ & Electricity & $\begin{array}{l}\text { Electricity purchasing price without competition, } \\
\text { electricity retail price }\end{array}$ \\
\hline $\mathbf{9}$ & Military goods & $\begin{array}{l}\text { Military equipments, army provisions, oil supply for } \\
\text { military use }\end{array}$ \\
\hline $\mathbf{1 0}$ & $\begin{array}{l}\text { Important transportation } \\
\text { services }\end{array}$ & $\begin{array}{l}\text { Pipeline transportation, port charge, airplane ticket } \\
\text { price and discount, railway ticket price, etc. }\end{array}$ \\
\hline $\mathbf{1 3}$ & Post services & $\begin{array}{l}\text { Postage for letter, parcel, newspaper, emergent mail, } \\
\text { etc. }\end{array}$ \\
\hline & Telecom services & $\begin{array}{l}\text { Financial service, geotechnical survey and design } \\
\text { service, specific intermediary service }\end{array}$ \\
\hline & services & imarge for fixed phone and mobile phone \\
\hline
\end{tabular}

Source: National Development and Planning Commission (2001).

In addition to controlling prices of commodities and services listed in the pricing catalogue, the government withholds the right of using other policy instruments to regulate market prices. For example, the price regulation fund can be used to stabilize market prices; government can implement the "temporary 
price-intervention policy" by limiting profit margin, setting price upper bounds and so on (The Price Department of the National Development and Reform Commission, 2009). The "temporary price-intervention policy" was employed in 2003 and 2008 to curb inflation.

Generally speaking, the price control policies in China today mainly target five kinds of commodities and services: a) commodities of great importance to national economy and people's lives, b) commodities using scarce resources, c) commodities of a natural monopoly nature, d) important utility services, and e) public welfare services. Take oil price as an example: According to current regulation, domestic oil prices can be adjusted when the average increase of the weighted average oil price of New York, Rotterdam and Singapore continuously exceeds $4 \%$ within 22 working days. Despite the already long adjustment interval, the pricing authority tends to maintain the domestic oil price even if the above condition is met, in the name of preventing inflation. As a result, domestic oil prices lag far behind international oil prices during an international oil price hike (see Figure 5). 


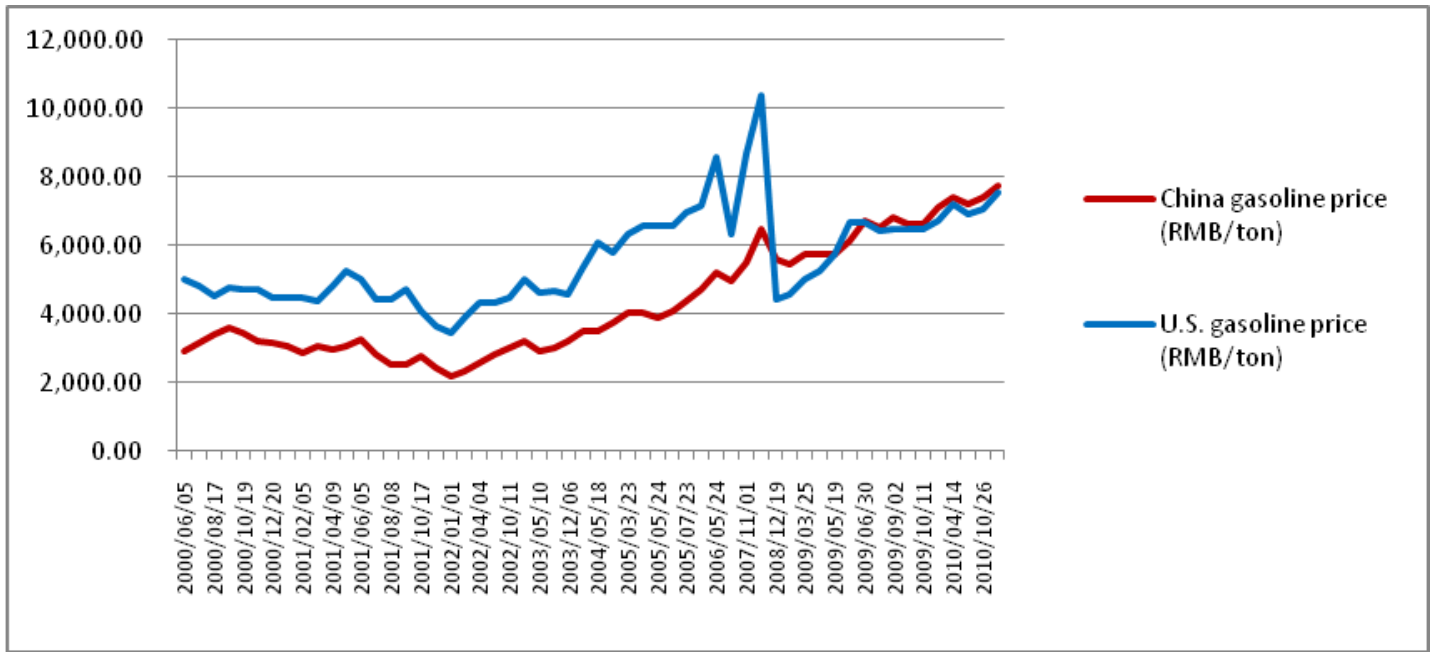

Fig.5 Gasoline price in China and the U.S.

Comparing an ideal price increase (using an input-output table) and actual price increase (from price indices) provides us with some insights into the impact of price control. For example, for industries like natural gas production and supply, during the 2007-08 oil-price shock, in order to maintain the profit level, an ideal price increase of $26.19 \%$ was required. However, the industry only managed to increase the price by $7 \%$. Some other industries under price control with a partial oil price pass-through are given in Figure 6. 


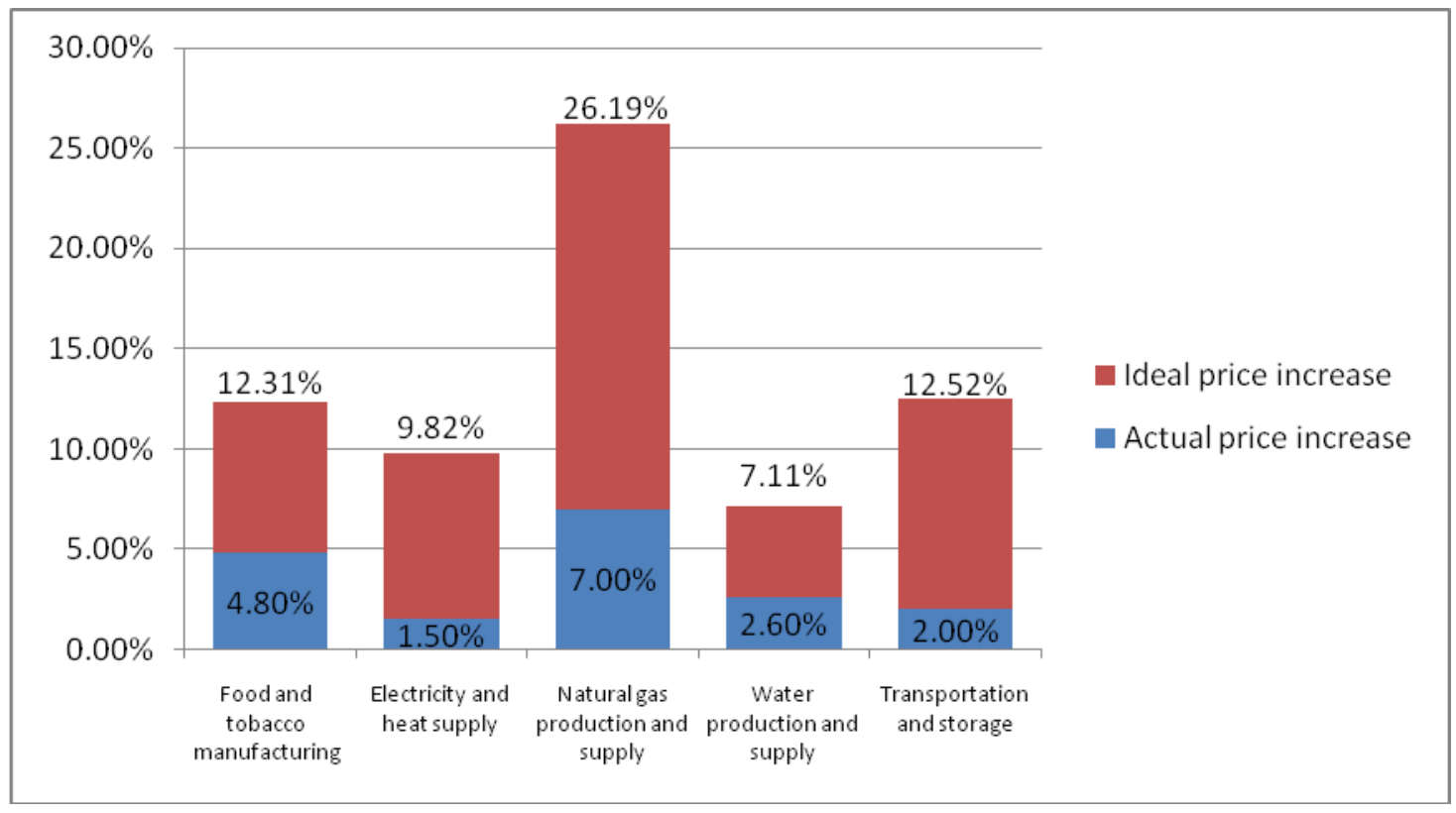

Fig.6 A comparison between ideal and actual price increases for five industries under price control

Despite the still rigorous control on price, it is well recognized that price control policy should be eventually eliminated through a gradual price reform. As a matter of the fact, price reform since 1978 has greatly deregulated China's market. The categories of commodities and services in pricing catalogue have been significantly reduced to 13 , compared with nearly 800 at the beginning of the reform. As a result, the current share of government regulated goods and services only accounts for $4.4 \%, 2.9 \%$ and $7.6 \%$ in the total sales of retail commodities, farm products and production materials, respectively (The Price Department of the National Development and Reform Commission, 2009). 